\title{
POLYCYCLIC AROMATIC HYDROCARBONS IN SMOKED DRY FERMENTED SAUSAGES WITH PROTECTED DESIGNATION OF ORIGIN Petrovská klobása FROM SERBIA
}

\author{
Biljana Škrbić $^{1}$, Nataša Đurišić-Mladenović ${ }^{1}$, Nada Mačvanin ${ }^{2}$, Ana Tjapkin ${ }^{1}$, \\ Snežana Škaljac ${ }^{1}$ \\ ${ }^{1}$ University of Novi Sad, Faculty of Technology, Bulevar cara Lazara 1, 21000 Novi Sad, Serbia \\ ${ }^{2}$ University of Novi Sad, Faculty of Medicine, Institute of Occupational Health, Novi Sad, Serbia \\ biljana@tf.uns.ac.rs
}

\begin{abstract}
The occurrence of polycyclic aromatic hydrocarbons (PAHs) in smoked dry fermented sausage with protected designation of origin Petrovská klobása from Serbia was determined by analyzing PAHs from the US EPA and EU priority lists. Peeled natural cased sausages smoked in industrial and traditional smokehouses were studied in order to assess the influence of smoking conditions on the PAH contents. The highest total concentration of EPA PAHs was found in the samples smoked in traditional smokehouse, being almost 15 times higher than the total EPA PAH content in sausages smoked in an industrial smokehouse; the content of EU PAHs in both types of smoked products were similar, being close to 1.5 $\mu \mathrm{g} / \mathrm{kg}$. The most abundant compound was phenanthrene, with an average content of about $31 \mu \mathrm{g} / \mathrm{kg}$ in traditionally smoked samples and about $3 \mu \mathrm{g} / \mathrm{kg}$ in industrially smoked samples. The concentrations of benzo $[a]$ pyrene as well as the total concentrations of benzo $[a]$ pyrene, benzo $[a]$ anthracene, benzo[b]fluranthene and chrysene (comprising the so-called "PAH4" group) were rather low in both types of smoked sausages, being well below the corresponding maximum allowed levels set by the latest European Regulation 835/2011 and not representing any risk to consumers' health.
\end{abstract}

Keywords: Petrovská klobása; polycyclic aromatic hydrocarbons; smoking; traditional sausages; PAH4

\section{ПОЛИЦИКЛИЧНИ АРОМАТИЧНИ ЈАГЛЕВОДОРОДИ ВО ЧАДЕНИ СУВИ ФЕРМЕНТИРАНИ КОЛБАСИ СО ОЗНАКА НА ПОТЕКЛО Petrovská klobása ОД СРБИЈА}

Анализирано е присуството на полициклични ароматични јаглеводороди (РАНs) во чаден сув колбас со ознака на потеклото, petrovská klobása, од Србија преку анализа на РАНs од приоритетните листи на US EPA и EU. Проучувани се излупени колбаси чадени во природна обвивка во индустриски и традиционални чадилници за да се оцени влијанието на условите за чадење на содржината на полициклични ароматични јаглеводороди во нив. Највисока вкупна концентрација на ЕРA PAНs беше најдена во примероците чадени во традиционална чадилница, која беше за околу 15 пати повисока во споредба со вкупната содржина на овие супстанции најдена во колбасите чадени во индустриска чадилница; содржината на EU PAHs во двата вида чадени производи беше слична и блиска до $1.5 \mu \mathrm{g} / \mathrm{kg}$. Најзастапено соединение беше фенантрен со средна содржина од околу $31 \mu \mathrm{g} / \mathrm{kg}$ во традиционално чадените примероци и околу $3 \mu \mathrm{g} / \mathrm{kg}$ во индустриски чадените примероци. Концентрацијата на бензо[a]пирен, како и вкупните

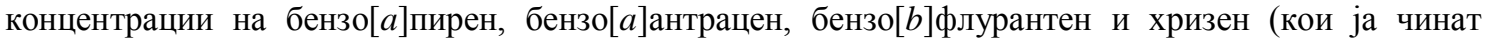
групата „РАН4“) беа ниски во двата вида чадени колбаси, и тоа значително пониски од соодветните максимално дозволени нивоа поставени со најновата европска регулатива 835/2011, така што не претставуваат никаков ризик за здравјето на потрошувачите во однос на присуството на полициклични ароматични јаглеводороди.

Клучни зборови: petrovská klobása; полициклични ароматични јаглеводороди; чадење; традиционални колбаси; РАН4 


\section{INTRODUCTION}

Smoking of meat and meat products is an ancient technology used not only to generate the special organoleptic profiles of smoked products, but also for the inactivating effect of smoke (and heat) on enzymes and microorganisms. Today, smoking technology relies mainly on the special effects of various sensory active components (phenol derivatives, carbonyls, organic acids and their esters, lactones, pyrazines, pyrols and furan derivates) contained in smoke for the aromatization of meat products to give it a specific organoleptic profile, which is widely demanded on the market [1]. On the other hand, incomplete wood combustion during the process of smoking can produce considerable amounts of polycyclic aromatic hydrocarbons - PAHs [2, 3], a group of organic compounds consisting of two or more condensed aromatic rings, which may be regarded as potentially genotoxic and carcinogenic to humans [4].

The United States Environmental Protection Agency (EPA) has classified seven PAHs (benzo $[a]$ pyrene, benzo $[a]$ anthracene, chrysene, benzo[ $b]$ fluoranthene, benzo $[k]$ fluoranthene, dibenzo $[a, h]$ anthracene and indeno[1,2,3-c,d]pyrene) as Group B2, probable human carcinogens [5], while the list of 16 EPA priority PAHs (naphthalene, acenaphthylene, acenaphthene, fluorene, phenanthrene, anthracene, fluoranthene, pyrene, benzo $[a]$ anthracene, chrysene, benzo[ $b]$ fluoranthene, benzo[ $k]$ flouranthene, benzo$[a]$ pyrene, dibenzo $[a, h]$ anthracene, benzo $[g, h, i]$ perylene, and indeno[1,2,3-c,d]pyrene) is often targeted for measurement in environmental samples.

The European Commission set harmonized maximum levels (MLs) for benzo[a]pyrene (BaP) in food for the first time in 2005 by Regulation (EC) 208/2005 [6], amending Regulation (EC) 466/2001 of 8 March 2001 [7] as regards PAHs. In the meantime, since Regulation (EC) 466/2001, setting maximum levels for other contaminants in foodstuffs, had been amended substantially many times, it was replaced in 2006 with Commission Regulation (EC) 1881/2006 [8], in which all the MLs for BaP previously defined by EC 208/2005 were included. One of the reasons why only MLs for $\mathrm{BaP}$ was set was that available data on the occurrence and relative proportions of other carcinogenic PAHs in food were considered insufficient by the Commission for setting further MLs. This is why the European Commission Recommendation 2005/108/EC [9] advised the Member States to monitor 15 priority PAHs (recommended by the Scientific Committee on Food [10]) together with one additional PAH, benzo[c]fluorene, recom- mended by the Joint FAO/WHO Expert Committee on Food Additives [11], hence comprising the EU $15+1$ PAH priority list. In accordance with this Recommendation, the Commission asked Member States to monitor PAHs in foodstuffs and to clarify the question whether $\mathrm{BaP}$ could be maintained as a marker for PAHs. On the basis of the obtained results it has been concluded that $\mathrm{BaP}$ alone is not a suitable indicator for the occurrence and toxicity of PAHs in food and that eight specified PAHs (PAH8), including $\mathrm{BaP}$, benzo[ $[a]$ anthracene, ben$\mathrm{zo}[b]$ fluoranthene, benzo[ $k]$ fluoranthene, benzo[ghi]perylene, chrysene, dibenzo[ $a, h]$ anthracene and indeno[1,2,3-cd]pyrene, for which oral carcinogenicity data are available, and/or a subgroup of these, PAH4, including BaP, chrysene, benz $[a]$ anthracene and benzo[ $b]$ fluoranthene, are more suitable markers [12]. Thus, from September $1^{\text {st }} 2012$ European Commission Regulation 835/2011 [13] has been applied, amending Regulation 1881/2006 by introducing new maximum levels for the sum of BaP, chrysene, benzo[a]anthracene and benzo[b]fluoranthene (PAH4), whilst maintaining a separate maximum level for $\mathrm{BaP}$ to ensure the comparability of previous and future data. The new maximum level for $\mathrm{BaP}$ in smoked meat and smoked meat products will be $2.0 \mu \mathrm{g} / \mathrm{kg}$ as of September 2014, while until then the level of $5.0 \mu \mathrm{g} / \mathrm{kg}$ also defined by previous Regulation 1881/2006 should be applied. As for the sum of PAH4 in the same foodstuffs group, it is set to $30.0 \mu \mathrm{g} / \mathrm{kg}$ till September 2014 and $12.0 \mu \mathrm{g} / \mathrm{kg}$ after this date [13].

Smoked meat products form a very important part of the human diet in Serbia. One of the traditional smoked meat products is Petrovská klobása, dry fermented sausage that has been produced in the nearby town of Bački Petrovac in the Autonomous Province of Vojvodina, Republic of Serbia. Because of its specific and recognizable quality, this product has been protected with a designation of origin (PDO) according to the Serbian legislation. It is produced without additives (nitrate, nitrite, glucono- $\delta$-lactone or others) and starter cultures in three stages: smoking, drying and fermentation.

The aim of this study was to determine and compare the content of $\mathrm{BaP}, \mathrm{PAH} 4$ and other compounds from the EU 15+1 PAHs priority list in traditionally prepared Petrovská klobása sausages submitted to smoking in traditional (direct smoking) and industrial (indirect smoking) smokehouses, in order to investigate an influence the smoking had on the PAH contents in the sausages and to assess the safety of the product in line with the EU legislation on PAHs. Moreover, knowing that dur- 
ing the smoking process a large number of different PAHs formed by the combustion of wood can reach smoked meat products, attention was also given to the group of more volatile low-molecularmass PAHs included in the list of 16 EPA PAHs. The results were compared with data on similar meat products (i.e. sausages) available in recently published studies. It is worth noting that this is the first attempt to study the content of PAHs in $P e$ trovská klobása.

\section{MATERIAL AND METHODS}

\subsection{Samples}

The sausages were produced in December 2008 according to the following recipe: minced lean pork meat $(80 \%)$ and pork fat $(20 \%)$ were mixed with home-made red hot paprika powder $(2.50 \%)$, salt $(1.80 \%)$, crushed garlic $(0.20 \%)$, caraway $(0.20 \%)$ and sugar $(0.15 \%)$. All ingredients were mixed manually for approximately 10 minutes. The mixture was stuffed into natural casings made from cleaned large intestines, $45-50 \mathrm{~mm}$ in diameter. After resting a day, the sausages were smoked in either a traditional (direct smoking) or an industrial (indirect smoking) smokehouse.

The groups of sausages sampled are given in Table 1, with sample labels and smoking/drying conditions. All determinations were made in three samples from each batch in duplicate.

\section{Table 1}

\section{Labels of the smoked sausages analyzed in this study with the respective smoking and drying conditions}

\begin{tabular}{|c|c|c|}
\hline $\begin{array}{c}\text { Sample } \\
\text { label }\end{array}$ & $\begin{array}{l}\text { Smoking } \\
\text { conditions }\end{array}$ & $\begin{array}{l}\text { Drying } \\
\text { conditions }\end{array}$ \\
\hline 0 & no smoking & no drying \\
\hline $\mathrm{I}_{1}$ & $\begin{array}{l}1 \text { day of indirect } \\
\text { smoking in indus- } \\
\text { trial smokehouse }\end{array}$ & $\begin{array}{l}45 \text { days, } 10^{\circ} \mathrm{C}, \\
75-90 \% \text { humidity }\end{array}$ \\
\hline $\mathrm{I}_{3}$ & $\begin{array}{l}3 \text { days of indirect } \\
\text { smoking in indus- } \\
\text { trial smokehouse }\end{array}$ & $\begin{array}{l}45 \text { days, } 10{ }^{\circ} \mathrm{C}, \\
75-90 \% \text { humidity }\end{array}$ \\
\hline $\mathrm{T}$ & $\begin{array}{l}10 \text { days of direct } \\
\text { smoking in tradi- } \\
\text { tional smokehouse }\end{array}$ & $\begin{array}{l}90 \text { days, } \\
2.6-12.4{ }^{\circ} \mathrm{C}, \\
43-93 \% \text { humidity }\end{array}$ \\
\hline
\end{tabular}

In the traditional smokehouse, smoke was produced by the combustion of cherry wood, with a distance of $3 \mathrm{~m}$ between the fire and the sausages, which came in direct contact with the smoke (direct smoking). This traditional way of meat smoking is applied in practice only during winter. The full smoking process in the traditional smokehouse lasted 10 days. Sausages from the industrial smokehouse coded as samples " $I_{1}$ " and " $I_{3}$ " (Table 1) were smoked during one and three days (each day smoking was performed 4 times for $30 \mathrm{~min}$ ), respectively, under controlled conditions. Smoke was produced by a Vemag glowing smoke generator $\mathrm{H}$ 504/C using beech wood, with an average smoke temperature of $28^{\circ} \mathrm{C}$. The smoke was transported to the smoking chamber through pipes (indirect smoking). Char particles, present in the smoke in a form of an aerosol, settle in the pipes so the smoke that reaches the sausages is partly purified. The industrial way of smoking is applied in practice during the whole year.

The sampling of sausages was performed during the drying period that allowed a moisture level of less than $35.0 \%$ to be reached [14]. The drying conditions are given in Table 1.

Non-smoked sausages were used as controls (samples "0").

\subsection{Chemicals}

All chemicals used were of analytical-reagent grade: methanol, cyclohexane, acetone and N,Ndimethylformamide (DMF), anhydrous sodium sulfate and potassium hydroxide, obtained from Centrohem (Serbia), and silica gel 60 (0.063-0.200 $\mathrm{mm}$ ) obtained from Merck (Germany). Solvents were distilled in glass before use. Silica gel and sodium sulfate were heated at $360^{\circ} \mathrm{C}$ for $4 \mathrm{~h}$. Distilled water was extracted with cyclohexane before use.

A standard mixture of $15+1$ EU priority PAHs benzo $[a]$ anthracene, benzo $[b]$ fluoranthene, benzo[j]fluoranthene, benzo[ $k]$ fluoranthene, benzo $[c]$ fluorene, benzo $[g, h, i]$ perylene, benzo $[a]$ pyrene, chrysene, cyclopenta $[c, d]$ pyrene, dibenzo $[a, h]$ anthracene, dibenzo $[a, e]$ pyrene, dibenzo $[a, h]$ pyrene, dibenzo $[a, i]$ pyrene, dibenzo $[a, l]$ pyrene, indeno[ $[1,2,3-$ $c, d$ ]pyrene and 5-methylchrysene dissolved in cyclohexane $(10 \mu \mathrm{g} / \mathrm{ml})$ was purchased from Dr. Ehrenstorfer (Augsburg, Germany). A standard mixture of 16 EPA priority PAHs acenaphthene, acenaphthylene, anthracene, benzo[ $a]$ anthracene, benzo $[b]$ fluoranthene, benzo[ $k]$ fluoranthene, benzo[ $g, h, i]$ perylene, benzo $[a]$ pyrene, chrysene, dibenzo $[a, h]$ anthracene, fluoranthene, fluorene, indeno[1,2,3$c, d]$ pyrene, naphthalene, phenanthrene and pyrene dissolved in cyclohexane was purchased from $\mathrm{Su}-$ pelco (Bellefonte, PA, USA). Calibration standard 
solutions of $15+1$ EU PAHs with concentrations in the $1-9 \mu \mathrm{g} / \mathrm{ml}$ range, and of 16 EPA PAHs with concentrations in the $1-20 \mu \mathrm{g} / \mathrm{ml}$ range, were prepared in toluene and stored at $4{ }^{\circ} \mathrm{C}$. Neat $1,3,5-$ triphenylbenzene (TPB) purchased from Supelco (Bellefonte, PA, USA) was dissolved in cyclohexane and used as an internal standard.

Filter paper was washed with cyclohexane prior to use. The laboratory glassware was washed with detergent, rinsed with distilled water and acetone and then heated to $130^{\circ} \mathrm{C}$ overnight prior to use.

During sample preparation glassware was wrapped in aluminum foil in order to prevent $\mathrm{PAH}$ degradation by light.

\subsection{Sample preparation}

After the casings were removed, the sausages were homogenized in a food blender. Homogenized samples were stored at $-20{ }^{\circ} \mathrm{C}$ until analyzed. The applied method for preparation of the samples has been described in detail previously by Larsson [15].

Briefly, fifty grams of homogenized sample were saponified with $150 \mathrm{ml}$ of methanolic 2M$\mathrm{KOH}$ solution in a Soxhlet apparatus placed in a water bath. After $6 \mathrm{~h}$ reflux (8 cycles/h), the alkaline mixture was cooled to room temperature and transferred to a $500 \mathrm{ml}$ separating funnel. Fifty $\mathrm{ml}$ of cyclohexane was added to the funnel as well as the methanol/water rinsings $(4+1$, in total $30 \mathrm{ml})$ of the condenser and the flask. The funnel was shaken and the layers were allowed to separate. The methanol/water layer was drained into another separating funnel and shaken with another $30 \mathrm{ml}$ of cyclohexane. The methanol/water phase was discarded and the cyclohexane phases were combined and washed successively with $30 \mathrm{ml}$ of methanol/water $(4+1), 30 \mathrm{ml}$ of methanol/water $(1+1)$ and twice with $30 \mathrm{ml}$ of water. Afterwards, the cyclohexane extract was shaken with 50- and 30$\mathrm{ml}$ volumes of $\mathrm{DMF} /$ water $(9+1)$, and then it was discarded, while the DMF/water phases were combined. After adding $80 \mathrm{ml}$ of water, the $\mathrm{DMF} /$ water phase was extracted successively with 50 and 30 $\mathrm{ml}$ of cyclohexane. The DMF/water layer was discarded, and the cyclohexane phases were combined and washed twice with $30 \mathrm{ml}$ of water. The washed cyclohexane solution was transferred to a $150 \mathrm{ml}$ round-bottomed flask and concentrated to about $1 \mathrm{ml}$ in a rotary evaporator (Heidolph, Germany) under reduced pressure at about $38{ }^{\circ} \mathrm{C}$. The concentrated extract was then transferred to the top of the silica gel $\left(5 \mathrm{~g}\right.$, dried at $360{ }^{\circ} \mathrm{C}, 8 \%$ deactivated) bed (covered with anhydrous sodium sul- fate) in a glass column, as well as the cyclohexane rinsings of the evaporation flask. The extract was allowed to run into the silica gel until the solvent was just above the bed. The column was then percolated with $100 \mathrm{ml}$ of cyclohexane: the first $23 \mathrm{ml}$ was discarded, while the 23- to 100-ml fraction with PAHs was collected and concentrated to about $0.5 \mathrm{ml}$ in a rotary evaporator. The concentrate was further transferred to a conical vial and evaporated to near dryness in a gentle stream of nitrogen; after the addition of the internal standard TPB (to a final concentration of $10 \mu \mathrm{g} / \mathrm{ml}$ ), the extract was reconstituted in $50 \mu \mathrm{l}$ of toluene (gravimetrically checked).

The set of samples analyzed was processed together with a blank to test for the background PAH levels in the materials.

\subsection{Analysis of PAHs}

Sample analysis was carried out using a DANI GC 1000 gas chromatograph equipped with a flame ionization detector (FID) and Restek Rtx 5 capillary column $(30 \mathrm{~m} \times 0.25 \mathrm{~mm}$ i.d. $\times 0.25 \mu \mathrm{m}$ film thickness). Helium was used as the carrier gas with a nominal initial flow through the column of 2 $\mathrm{ml} / \mathrm{min}$, and the injector and detector temperatures were maintained at $280{ }^{\circ} \mathrm{C}$ and $300{ }^{\circ} \mathrm{C}$, respectively. A volume of $1 \mu \mathrm{l}$ of extract was injected into the GC system in splitless mode with a purge time of $4 \mathrm{~min}$. In order to achieve the best separation of all of the studied PAHs, the following program ("program A") was applied: initial temperature $70^{\circ} \mathrm{C}$, held for $1 \mathrm{~min}$, increased at a rate of $20^{\circ} \mathrm{C} / \mathrm{min}$ to $160{ }^{\circ} \mathrm{C}$, then increased at a rate of $3{ }^{\circ} \mathrm{C} / \mathrm{min}$ to $180{ }^{\circ} \mathrm{C}$, held for $3 \mathrm{~min}$, then increased at a rate of $3{ }^{\circ} \mathrm{C} / \mathrm{min}$ to $200{ }^{\circ} \mathrm{C}$, increased at a rate of $0.5^{\circ} \mathrm{C} / \mathrm{min}$ to $210{ }^{\circ} \mathrm{C}$ and increased at a rate of $4{ }^{\circ} \mathrm{C} / \mathrm{min}$ to $310^{\circ} \mathrm{C}$ and held for 10 minutes. This temperature program provided good separation of compounds like cyclopenta[ $[c, d]$ pyrene (CPP), benzo $[a]$ anthracene $(\mathrm{BaA})$ and chrysene (CHR) (Fig. 1a). In order to avoid doubtful results on $\mathrm{BaP}$, whose peak was fully separated from others in the case of standard solutions but not in the case of meat extract, where a significant matrix peak appeared very close to the BaP peak (Fig. 1a), another temperature program ("program B") was used concurrently for BaP identification and quantification as well as for the confirmation of other PAHs: initial temperature $50{ }^{\circ} \mathrm{C}$, held for $4 \mathrm{~min}$, increased at a rate of $25^{\circ} \mathrm{C} / \mathrm{min}$ to $200{ }^{\circ} \mathrm{C}$ and then increased at a rate of $4{ }^{\circ} \mathrm{C} / \mathrm{min}$ to $310^{\circ} \mathrm{C}$, and held for 10 min. Temperature program $\mathrm{B}$ allowed separation of the $\mathrm{BaP}$ peak from the significant nearby matrix 
peak seen in Figure 1a; however, the separation of isomeric compounds (CPP, $\mathrm{BaA}$, and $\mathrm{CHR}$ ) was poorer than in the case of program $\mathrm{A}$, while $\mathrm{BkF}$ and $\mathrm{BjF}$ coeluted fully (Fig. 1b).

PAH peaks were identified by comparison of sample chromatograms with the chromatogram of the PAH standards. The quantification of PAHs was carried out using the internal standard method.

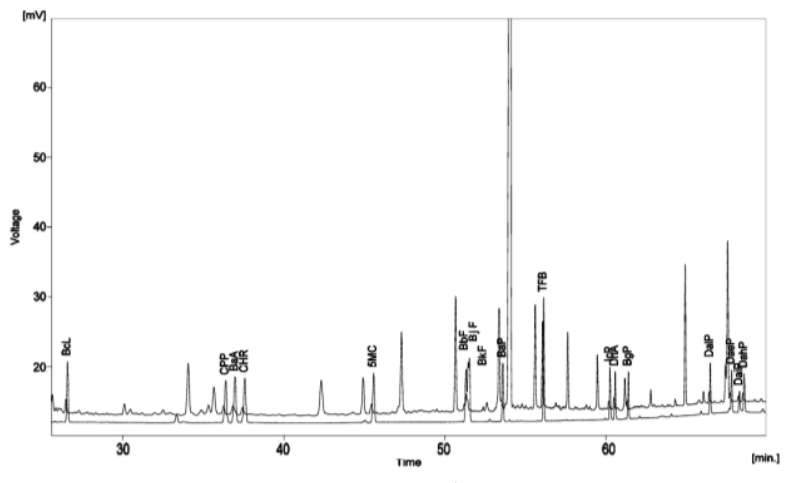

a)

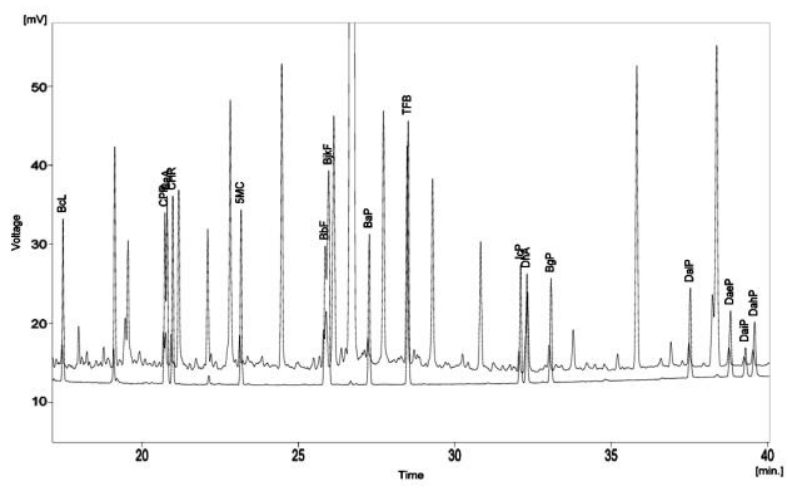

b)

Fig. 1. Chromatograms of the mixed standard solution (6.78 $\mu \mathrm{g} / \mathrm{ml}$ of each PAH; lower line in the front) and the purified extract (upper line in the back) obtained from a contaminated sausage sample provided during the proficiency test organized by the EC-JRC Institute for Reference Materials and Measurements (IRMM, Geel, Belgium) with the assigned values for $15+1$ EU PAHs given in Table 3. a) Temperature program A: $70{ }^{\circ} \mathrm{C}, 1 \mathrm{~min}, 20^{\circ} \mathrm{C} / \mathrm{min}, 160{ }^{\circ} \mathrm{C}, 3{ }^{\circ} \mathrm{C} / \mathrm{min}, 180{ }^{\circ} \mathrm{C}, 3 \mathrm{~min}, 3$ ${ }^{\circ} \mathrm{C} / \mathrm{min}, 200^{\circ} \mathrm{C}, 0.5^{\circ} \mathrm{C} / \mathrm{min}, 210^{\circ} \mathrm{C}, 4^{\circ} \mathrm{C} / \mathrm{min}, 310^{\circ} \mathrm{C}, 10 \mathrm{~min}$, b) temperature program $\mathrm{B}: 50^{\circ} \mathrm{C}, 4 \mathrm{~min}, 25^{\circ} \mathrm{C} / \mathrm{min}, 200^{\circ} \mathrm{C}$, $4{ }^{\circ} \mathrm{C} / \mathrm{min}, 310^{\circ} \mathrm{C}, 10 \mathrm{~min}$.

\subsection{Method performance}

The method's performance was determined by checking its linearity and limits of detection (LOD) as well as the accuracy.

A calibration curve for each PAH was obtained by running six mixed standard solutions of PAHs in which the concentration of the internal standard was the same $(10 \mu \mathrm{g} / \mathrm{ml})$; the final (exact) concentrations of all compounds were checked gravimetrically. The ratios of the peak area of each $\mathrm{PAH}$ and the internal standard $\left(\mathrm{A}_{\mathrm{PAH} /} \mathrm{A}_{\mathrm{IS}}\right)$ were plotted against the ratios of the mass of the PAH compound and the internal standard $\left(\mathrm{m}_{\mathrm{PAH}} / \mathrm{m}_{\mathrm{IS}}\right)$ to obtain a linear graph $Y=\mathrm{m} X+\mathrm{b}$, where $Y=$ $A_{\mathrm{PAH} /} / A_{\mathrm{IS}}$ and $X=m_{\mathrm{PAH}} / m_{\mathrm{IS}}$.

In order to assess the accuracy of the applied method, a contaminated sausage (PT) sample provided during the proficiency test organized by the EC-JRC Institute for Reference Materials and Measurements (IRMM, Geel, Belgium) with assigned values for $16 \mathrm{EU}$ PAHs were prepared and analyzed in duplicate.

\section{RESULTS AND DISCUSSION}

According to EC Regulation 836/2011 [16], where no specific methods for the determination of contaminants in foodstuffs are prescribed at the European Union level, laboratories may select any validated method of analysis for the respective matrix provided that the selected method meets the specific performance criteria set out in the Regulation. In this work a method based on GC/FID analysis similar to that in Larsson [15] was used and validated. Apart from GC based methods, high performance liquid chromatography with fluorescence detection has also been used intensively for determination of PAHs in food $[17,18]$.

The method was evaluated by in-house validation against the performance criteria for methods of analysis for polycyclic aromatic hydrocarbons in foodstuffs defined by EC Regulation 836/2011 [16]. This latest Regulation [16] sets acceptable recoveries for four substances from the PAH4 group in the $50-120 \%$ range, while the LOD for each of these four substances should be below $0.3 \mu \mathrm{g} / \mathrm{kg}$.

The LODs ranged from $0.12 \mu \mathrm{g} / \mathrm{kg}$ to 0.53 $\mu \mathrm{g} / \mathrm{kg}$ (Table 2), with the LODs of PAH4 compounds in the $0.17-0.30 \mu \mathrm{g} / \mathrm{kg}$ range.

The chromatograms of the PT sample extract obtained by applying the described temperature programs are shown in Figure 1 together with the corresponding chromatograms of one of the calibration standards. The obtained recovery results are shown in Table 3 with the assigned and measured values for each of the EU $15+1$ priority PAHs. The presented values are averages of duplicate samples. The recoveries for EU $15+1$ priority PAHs were in the range from $50 \%$ to $79 \%$, being in accordance with EC Regulation 836/2011 [16].

For all PAH compounds investigated under both temperature programs, the correlation coefficients of the calibration curves were higher than 0.9900 , being in compliance with the general crite- 
ria for chromatographic determination described by EPA method 8000B (it should be mentioned here that there is no requirement for the correlation coefficients according to EC Regulation 836/ 2011). Thus, the GC/FID method used here showed good separation of the PAHs analyzed and the validation data indicated good and acceptable accuracy for all the compounds of interest including $\mathrm{BaP}$ and $\mathrm{PAH} 4$ compounds.

The results obtained from analyzing sausage samples for the presence of $15+1 \mathrm{EU}$ and $16 \mathrm{EPA}$ priority PAHs are given in Table 4 . The presented values are means calculated for three samples analyzed in duplicate and corrected for recoveries.

The non-smoked sausages (" 0 " samples) were analyzed as control samples in order to determine the contribution from the environment, animal feed and added ingredients (e.g. spices). However, PAHs were not found in " 0 " samples in quantities detectable by the selected method (Table 4). Thus, the presence of PAHs in samples of the smoked products should be attributed solely to the smoking procedure.

Concerning the occurrence of PAHs in the smoked products, it has been proven that PAHs accumulate mainly on the product's surface, due to their lipophilic nature, but some diffusion can also take place to inner layers of the product [1]. In fact, PAHs penetrate into the inner layers during processing and also during storage, stabilizing their concentration after some time [1].
Table 2

\section{Limits of detection $(\mu \mathrm{g} / \mathrm{kg})$ for $E U$ and $E P A$} priority PAHs

\begin{tabular}{|c|c|c|c|c|}
\hline PAHs & & EU & EPA & LOD \\
\hline Benzo $[c]$ fluorene & $\mathrm{BcL}$ & $\mathrm{x}$ & & 0.37 \\
\hline Cyclopenta $[c, d]$ pyrene & CPP & $\mathrm{x}$ & & 0.25 \\
\hline Benzo $[a]$ anthracene & $\mathrm{BaA}$ & $\mathrm{x}$ & $\mathrm{x}$ & 0.21 \\
\hline Chrysene & CHR & $\mathrm{x}$ & $\mathrm{x}$ & 0.30 \\
\hline 5-methylchrysene & $5 \mathrm{MC}$ & $\mathrm{x}$ & & 0.31 \\
\hline Benzo $[b]$ fluoranthene & $\mathrm{BbF}$ & $\mathrm{x}$ & $\mathrm{x}$ & 0.18 \\
\hline Benzo[j]fluoranthene & $\mathrm{BjF}$ & $\mathrm{x}$ & & 0.24 \\
\hline Benzo $[k]$ fluoranthene & $\mathrm{BkF}$ & $\mathrm{x}$ & $\mathrm{x}$ & 0.25 \\
\hline Benzo $[a]$ pyrene & $\mathrm{BaP}$ & $\mathrm{x}$ & $\mathrm{x}$ & 0.17 \\
\hline Indeno[1,2,3-cd]pyrene & IcP & $\mathrm{x}$ & $\mathrm{x}$ & 0.26 \\
\hline Dibenzo $[a, h]$ anthracene & $\mathrm{DhA}$ & $\mathrm{x}$ & $\mathrm{x}$ & 0.33 \\
\hline Benzo $[g, h, i]$ perylene & $\mathrm{BgP}$ & $\mathrm{x}$ & $\mathrm{x}$ & 0.37 \\
\hline Dibenzo $[a, l]$ pyrene & DalP & $\mathrm{x}$ & & 0.53 \\
\hline Dibenzo $[a, e]$ pyrene & DaeP & $\mathrm{x}$ & & 0.52 \\
\hline Dibenzo $[a, i]$ pyrene & DaiP & $\mathrm{x}$ & & 0.32 \\
\hline Dibenzo $[a, h]$ pyrene & DahP & $\mathrm{x}$ & & 0.43 \\
\hline Naphthalene & Naph & & $\mathrm{x}$ & 0.12 \\
\hline Acenaphthylene & Acy & & $\mathrm{x}$ & 0.16 \\
\hline Acenaphthene & Ace & & $\mathrm{x}$ & 0.15 \\
\hline Fluorene & Fln & & $\mathrm{x}$ & 0.19 \\
\hline Phenanthrene & Phe & & $\mathrm{x}$ & 0.18 \\
\hline Anthracene & Ant & & $\mathrm{x}$ & 0.21 \\
\hline Fluoranthene & Flt & & $\mathrm{x}$ & 0.17 \\
\hline Pyrene & Pyr & & $\mathrm{x}$ & 0.21 \\
\hline
\end{tabular}

Ta ble 3

The accuracy of the applied method determined for the contaminated sausage sample provided during the proficiency test organized by EC-JRC IRMM

\begin{tabular}{|c|c|c|c|c|}
\hline PAHs & & $\begin{array}{c}\text { Assigned } \\
(\mu \mathrm{g} / \mathrm{kg})\end{array}$ & $\begin{array}{c}\text { Measured } \\
(\mu \mathrm{g} / \mathrm{kg})\end{array}$ & $\begin{array}{c}\text { Recovery }^{\mathrm{a}} \\
(\%)\end{array}$ \\
\hline Benzo $[c]$ fluorene & $\mathrm{BcL}$ & 3.9 & 2.4 & 61 \\
\hline Cyclopenta $[c, d]$ pyrene & $\mathrm{CPP}$ & 6.0 & 3.8 & 63 \\
\hline Benzo $[a]$ anthracene & $\mathrm{BaA}$ & 5.9 & 3.5 & 59 \\
\hline Chrysene & CHR & 6.4 & 3.4 & 53 \\
\hline 5-methylchrysene & $5 \mathrm{MC}$ & 6.2 & 3.2 & 51 \\
\hline Benzo[b]fluoranthene & $\mathrm{BbF}$ & 4.1 & 2.8 & 68 \\
\hline Benzo[j]fluoranthene & $\mathrm{BjF}$ & 9.2 & 5.4 & 59 \\
\hline Benzo[k]fluoranthene & $\mathrm{BkF}$ & 5.2 & 2.6 & 50 \\
\hline Benzo $[a]$ pyrene & $\mathrm{BaP}$ & 5.3 & 3.2 & 61 \\
\hline Indeno $[1,2,3-c d]$ pyrene & $\mathrm{IcP}$ & 5.2 & 4.1 & 79 \\
\hline Dibenzo $[a, h]$ anthracene & $\mathrm{DhA}$ & 7.7 & 4.9 & 63 \\
\hline Benzo $[g, h, i]$ perylene & $\mathrm{BgP}$ & 4.7 & 2.8 & 59 \\
\hline Dibenzo[ $[a, l]$ pyrene & DalP & 7.7 & 3.9 & 51 \\
\hline Dibenzo[a,e]pyrene & DaeP & 7.1 & 3.9 & 55 \\
\hline Dibenzo $[a, i]$ pyrene & DaiP & 5.6 & 3.0 & 53 \\
\hline Dibenzo $[a, h]$ pyrene & DahP & 9.9 & 5.1 & 52 \\
\hline
\end{tabular}

${ }^{\text {a }}$ Calculated as the measured value divided by the assigned value multiplied by 100 . 
T a ble 4

Concentration $(\mu \mathrm{g} / \mathrm{kg})$ of $15+1 \mathrm{EU}$ and $16 \mathrm{EPA}$ priority PAHs in sausage samples

\begin{tabular}{|c|c|c|c|c|c|}
\hline PAHs & & $\mathbf{0}$ & $\mathbf{I}_{1}$ & $\mathbf{I}_{3}$ & $\mathbf{T}$ \\
\hline Benzo[c]fluorene & $\mathrm{BcL}$ & nd & nd & nd & nd \\
\hline Cyclopenta $[c, d]$ pyrene & $\mathrm{CPP}$ & nd & nd & nd & nd \\
\hline Benzo $[a]$ anthracene & $\mathrm{BaA}$ & nd & nd & nd & nd \\
\hline Chrysene & CHR & nd & 0.32 & 0.34 & 0.48 \\
\hline 5-methylchrysene & $5 \mathrm{MC}$ & nd & nd & nd & nd \\
\hline Benzo $[b]$ fluoranthene & $\mathrm{BbF}$ & nd & nd & 1.06 & 0.50 \\
\hline Benzo[j]fluoranthene & $\mathrm{BjF}$ & nd & nd & nd & nd \\
\hline Benzo $[k]$ fluoranthene & $\mathrm{BkF}$ & nd & nd & nd & nd \\
\hline Benzo $[a]$ pyrene & $\mathrm{BaP}$ & nd & 0.51 & 0.28 & 0.51 \\
\hline Indeno $[1,2,3-c, d]$ pyrene & $\mathrm{IcP}$ & nd & nd & nd & nd \\
\hline Dibenzo $[a, h]$ anthracene & $\mathrm{DhA}$ & nd & nd & nd & nd \\
\hline $\operatorname{Benzo}[g, h, i]$ per & $\mathrm{BgP}$ & nd & nd & nd & nd \\
\hline Dibenzo[a,l]pyrene & DalP & nd & nd & nd & nd \\
\hline Dibenzo[a,e]pyrene & DaeP & nd & nd & nd & nd \\
\hline Dibenzo $[a, i]$ pyrene & DaiP & nd & nd & nd & nd \\
\hline$[a, h]$ pyrene & DahP & nd & nd & nd & nd \\
\hline Naphtl & Naph & nd & nd & nd & nd \\
\hline Acenaphthylene & Acy & nd & nd & nd & nd \\
\hline Acenaphthene & Ace & nd & nd & nd & nd \\
\hline Fluo & Fln & nd & nd & nd & 0.34 \\
\hline Phenanthrene & Phe & nd & 3.01 & 0.29 & 30.74 \\
\hline Anthracene & Ant & nd & nd & nd & 7.13 \\
\hline Fluoranthene & Flt & nd & 1.57 & 0.70 & 3.78 \\
\hline Pyrene & Pyr & nd & nd & 0.28 & 0.32 \\
\hline $\mathrm{PAH} 4^{\mathrm{b}}$ & & 0 & 0.83 & 1.68 & 1.49 \\
\hline $15+1 \mathrm{EU}$ PAH & & 0 & 0.83 & 1.68 & 1.49 \\
\hline 16 EPA PAHs ${ }^{b}$ & & 0 & 5.41 & 2.95 & 43.80 \\
\hline
\end{tabular}

nd - Not detected, i.e. less than the respective limit of detection (LOD) given in Table 2

${ }^{\mathrm{b}}$ Calculated as the lower bound as required by Commission Regulation EC835/2011 [13].

The penetration rate depends on the distance of the products from the heating source [1] as well as on product characteristics such as water activity, fat content [19] and surface/mass ratio [20]. Afterwards, a decrease in PAH content is expected, caused by light decomposition and interaction with other components in the product [1].

In the analyzed samples of peeled sausages, $\mathrm{BaP}$ was detected in very low quantities (Table 4): in sausages smoked for one day in the industrial smokehouse followed by drying for 45 days (" $\mathrm{I}_{1}$ " samples), as well as in the sausages smoked in the traditional smokehouse for 10 days and dried over 90 days ("T" samples), it was detected at a concentration of $0.51 \mu \mathrm{g} / \mathrm{kg}$, while it was found at a slightly lower level $(0.28 \mu \mathrm{g} / \mathrm{kg})$ in sausages smoked over three days in the industrial smoke- house and left to dry 45 days ("I 3 " samples). Still, the differences between detected contents were not marked, as these values were in the range between the LOD $(0.17 \mu \mathrm{g} / \mathrm{kg})$ and the limit of quantification $(0.51 \mu \mathrm{g} / \mathrm{kg})$ for BaP. In general, it could be said that smoking in either industrial or traditional smokehouses introduced $\mathrm{BaP}$ into the internal layers of the sausages in negligible amounts, as all measured levels of $\mathrm{BaP}$ were far below the current legal limit of $5 \mu \mathrm{g} / \mathrm{kg}$ set for $\mathrm{BaP}$ by the EU for smoked meat and smoked meat products [13]. The found BaP levels were also below the limit of 2.0 $\mu \mathrm{g} / \mathrm{kg}$ that will be applied from September 2014 in accordance with EC 835/2011 [13].

The concentrations of other individual EU priority PAHs were below their limits of detection, except for benzo[b]fluoranthene (BbF) and chrysene (CHR). BbF was identified in the samples of sausages subjected to a full smoking process, with a higher concentration in sausages smoked in an industrial smokehouse $(1.06 \mu \mathrm{g} / \mathrm{kg})$ than in those from the traditional smokehouse $(0.50 \mu \mathrm{g} / \mathrm{kg})$. CHR was found in similar and negligible concentrations in the " $\mathrm{I}_{1}$ ", " $\mathrm{I}_{3}$ " and " $\mathrm{T}$ " samples, being close to the respective LOD $(0.30 \mu \mathrm{g} / \mathrm{kg})$. Dibenzo[a,l]pyrene, with much stronger carcinogenic potential than $\mathrm{BaP}$ [21], was not detected in any of the samples.

The total concentration of $\mathrm{BaA}, \mathrm{CHR}, \mathrm{BbF}$ and $\mathrm{BaP}$, i.e. the $\mathrm{PAH} 4$ concentration, calculated as the lower bound (Table 4) as requested by EC Regulation 835/2011 [13], was rather similar in "I $\mathrm{I}_{3}$ " and " $\mathrm{T}$ " samples of dried sausages that had been fully smoked in industrial and traditional smokehouses, respectively (1.68 and $1.49 \mu \mathrm{g} / \mathrm{kg}$, respectively). In both cases, the values were far below the $30.0 \mu \mathrm{g} / \mathrm{kg}$ set by the latest EC Regulation [13], and also below the limit of $12 \mu \mathrm{g} / \mathrm{kg}$ that shall be applied from September 2014. Comparing the " $I_{1}$ " and "I $\mathrm{I}_{3}$ " samples, the enhancement of the PAH4 content from 0.83 to $1.68 \mu \mathrm{g} / \mathrm{kg}$ could be seen primarily as a result of the enhanced occurrence of $\mathrm{BbF}$ in the fully smoked product (" $\mathrm{I}_{3}$ " sample), i.e. its absence in the partially smoked product ("I " sample). Since no other EU PAHs were detected, the PAH4 contents of the products also reflected the total $15+1$ EU PAH contents (Table 4).

Considering the PAHs from the EPA priority list, phenanthrene, anthracene, fluoranthene, fluorene and pyrene were found in samples of dried sausages smoked in the traditional smokehouse, while in samples from the industrial smokehouse only phenanthrene and fluoranthene were 
found (with traces of pyrene detected only in " $\mathrm{I}_{3}$ " samples). The average concentrations of phenanthrene, anthracene, and fluoranthene detected in " $\mathrm{T}$ " samples were significantly higher than in both "I" samples, suggesting that direct contact of the smoke with the product can introduce significant levels of volatile PAHs into the internal layers of sausages. Several studies reporting PAHs profiles in smoked meat products $[1,19,20,22-26]$ have shown similar profiles with a prevalence of light PAHs over heavy compounds despite the variety of conditions applied during different manufacturing procedures (e.g. smoking practices). As shown by Sttumpe-Viksna et al. [26], the prevalence of light PAHs can be attributed to the composition of the smoke itself, independent of the wood used in the combustion and smoking procedure (direct/indirect), since these low molecular weight compounds are usually found in higher amounts.

The highest average sum of 16 EPA PAHs was $43.80 \mu \mathrm{g} / \mathrm{kg}$ for the samples smoked for 10 days in the traditional smokehouse, which is significantly higher than the sums obtained for industrially smoked samples. This was primarily the result of the high concentrations of phenanthrene and anthracene in " $T$ " samples compared to both types of samples from an industrial smokehouse, which could be attributed to the influence of the direct smoking.

In order to have a better overview of the obtained results, the data from this study were compared with the data reported previously for smoked sausages (Table 5). Even though different production conditions (e.g. formulations, smoking, etc.) have been used for the products shown in Table 5, the results for $\mathrm{BaP}, \mathrm{PAH} 4$, and phenanthrene are generally in good agreement. It should also be mentioned that the concentrations of selected PAHs in the smoked meat products (Table 5) are rather similar to those measured in barbecued muscle foods; for instance, Viegas et al. [18] reported the following average concentrations of $\mathrm{BaP}, \mathrm{PAH} 4$ and phenanthrene in meat grilled over charcoal: 0.4 $\mu \mathrm{g} / \mathrm{kg}, 2.33 \mu \mathrm{g} / \mathrm{kg}$ and $7.74 \mu \mathrm{g} / \mathrm{kg}$ in beef samples; $4.72 \mu \mathrm{g} / \mathrm{kg}, 38.01 \mu \mathrm{g} / \mathrm{kg}$ and $49.29 \mu \mathrm{g} / \mathrm{kg}$ in salmon samples; and $3.14 \mu \mathrm{g} / \mathrm{kg}, 18.18 \mu \mathrm{g} / \mathrm{kg}$ and 27.86 $\mu \mathrm{g} / \mathrm{kg}$ in chicken samples, respectively.

The risk associated with the consumption of the Petrovská klobása was also evaluated, following the approach based on the margin of exposure (MOE) as recommended by EFSA [12]. Specifically, the MOE approach to exposure calculation is based on the bench mark dose lower confidence limit for a $10 \%$ increase in the number of tumor bearing animals compared to control animals $\left(\mathrm{BMDL}_{10}\right)$. This methodology is based both in the compound's carcinogenic capacity and the consumers daily intake, where MOEs close to or less than 25000 or 10000 for representative mean or high level consumers (i.e. intakes), respectively, indicate a potential concern for consumer health and a possible need for risk management action [12]. Considering a mean consumption of $11 \mathrm{~g}$ of dry fermented sausages per day (data taken from the Serbian market basket for January 2011 [27]) by a person weighting $60 \mathrm{~kg}$, this would represent a daily intake of up to $0.09 \mathrm{ng} / \mathrm{kg} \mathrm{b.w}$. and 0.27 $\mathrm{ng} / \mathrm{kg}$ b.w. for BaP and PAH4, respectively. Dividing the respective $\mathrm{BMDL}_{10}(0.07 \mathrm{mg} / \mathrm{kg}$ b.w. per day for $\mathrm{BaP}$ and $0.34 \mathrm{mg} / \mathrm{kg}$ b.w. per day for PAH4 [12]) by the calculated daily intake of BaP and $\mathrm{PAH} 4$, the obtained MOE values (rounded to the nearest hundred: 777800 and 1259300 , respectively) are much higher than the reference values (10000 and 25000) according to EFSA [12], indicating that Petrovská klobása smoked either in industrial or traditional smokehouse would be of low concern to consumers' health, even in the case of consumption rates higher than the one considered here (i.e. $>11 \mathrm{~g} /$ day of the smoked sausage).

Finally, it could be concluded that samples of Petrovská klobása sausages produced in Vojvodina Province, Serbia, with protected designation of origin, showed significantly higher total contents of analyzed PAHs if smoked directly in a traditional smokehouse compared to samples smoked indirectly in an industrial smokehouse, mostly due to the greater levels of light PAHs, like phenanthrene and anthracene, while the difference was only slight in relation to compounds belonging to the PAH4 group (benzo[ $[a]$ pyrene, benzo $[a]$ anthracene, chrysene, benzo[ $b]$ fluoranthene). Under both smoking styles, benzo[ $[a]$ pyrene and the PAH4 group did not exceed the current limits of 5 $\mu \mathrm{g} / \mathrm{kg}$ and $30 \mu \mathrm{g} / \mathrm{kg}$, respectively, established by EU legislation for this kind of product. Moreover, the results indicated that the production of smoked traditional meat sausages is in compliance with the limits of benzo $[a]$ pyrene and PAH4 that will be applied from September 2014. According to the 2008 EFSA recommendations, the detected EU PAH levels in samples of Petrovská klobása do not represent any significant risk to consumers' health. 


\section{Table 5}

Comparison of the results on BaP, PAH4, and phenanthrene (Phe) levels in different smoked sausages $(\mu g / \mathrm{kg})$

\begin{tabular}{|c|c|c|c|c|}
\hline Source & Sausage type ${ }^{a}$ & $\mathrm{BaP}$ & PAH4 & Phe \\
\hline $\begin{array}{l}\text { This } \\
\text { study }\end{array}$ & $\begin{array}{l}\text { Serbian traditional smoked meat (pork) sausage, } \\
\text { Petrovská klobása, natural casing, } 20 \% \text { fat: } \\
\text { indirect smoking for } 3 \text { days, drying for } 45 \text { days } \\
\text { direct smoking for } 10 \text { days, drying for } 90 \text { days }\end{array}$ & $\begin{array}{l}0.28 \\
0.51\end{array}$ & $\begin{array}{l}1.68 \\
1.49\end{array}$ & $\begin{array}{c}0.29 \\
30.74\end{array}$ \\
\hline \multirow{2}{*}[1]{} & $\begin{array}{l}\text { Portuguese traditional smoked meat (pork) sausages, } \\
\text { Chouriço Grosso: }\end{array}$ & & & \\
\hline & $\begin{array}{l}\text { natural casings, } 15-25 \% \text { fat, } 40 \text { days under discontinuous } \\
\text { (direct) smoking }\end{array}$ & $0.68-3.53$ & $6.35-44.47$ & $179.73-1078.50$ \\
\hline \multirow{5}{*}{ [22] } & $\begin{array}{l}\text { Portuguese traditional dry fermented smoked meat (pork) } \\
\text { sausages, Chouriço type, } 8 \text { days smoking for } 4 \mathrm{~h} / \text { day: }\end{array}$ & & & \\
\hline & collagen casing/indirect smoking, $20 \%$ fat ( $40 \%$ fat) & $0.09(0.23)$ & $4.21(7.17)$ & $8.40(9.11)$ \\
\hline & collagen casing/direct smoking, $20 \%$ fat( $40 \%$ fat) & $0.21(0.24)$ & $4.77(9.12)$ & $11.82(9.13)$ \\
\hline & hog casings/indirect smoking, $20 \%$ fat (40\% fat) & $0.32(0.19)$ & $6.38(8.26)$ & $28.86(25.36)$ \\
\hline & hog casings/direct smoking, $20 \%$ fat (40\% fat) & $0.31(0.27)$ & $7.32(10.35)$ & $32.05(29.19)$ \\
\hline \multirow{9}{*}{ [23] } & $\begin{array}{l}\text { Portuguese traditional smoked meat sausages in natural } \\
\text { casings, direct smoking: }\end{array}$ & & & \\
\hline & from Alentejo region: & & & \\
\hline & Chouriço de carne, 5 days smoking, $25.1 \%$ fat & 0.38 & 4.55 & \\
\hline & Painho, 15 days smoking, $24.2 \%$ fat & 0.63 & 6.38 & 331.51 \\
\hline & Paio tradicional, 30 days smoking, $40.0 \%$ fat & 0.36 & 4.33 & 619.68 \\
\hline & from Trás-os-Montes region: & & & \\
\hline & Alheira, unknown smoking period, $16.0 \%$ fat & 1.48 & 101.42 & 187.44 \\
\hline & Chouriço de carne, unknown smoking period, $20.6 \%$ fat & 3.62 & 176.33 & 304.28 \\
\hline & Salpicão, unknown smoking period, $14.4 \%$ fat & 4.75 & 294.50 & 731.99 \\
\hline$[24]$ & $\begin{array}{l}\text { Frankfurter type meat (pork and beef) sausage in natural } \\
\text { casing, } 34 \% \text { fat, direct smoking under different regimes, } \\
\text { scaled for } 25 \text { min at } 75^{\circ} \mathrm{C} \text { after the smoking }\end{array}$ & $0.11-0.48$ & $1.10-3.16$ & $-{ }^{\mathrm{b}}$ \\
\hline \multirow{3}{*}{ [20] } & $\begin{array}{l}\text { Spanish traditional smoked meat (pork) sausages } \\
\text { in natural casings, produced by different industrial } \\
\text { pork manufacturers: }\end{array}$ & & & \\
\hline & $\begin{array}{l}\text { Androlla }- \text { traditional smoking } 8-10 \text { days, } \\
\text { drying } 1-2 \text { months }\end{array}$ & 0.49 & 2.71 & 15.1 \\
\hline & $\begin{array}{l}\text { Botillo - traditional smoking } 7-15 \text { days, } \\
\text { drying up to } 3 \text { months }\end{array}$ & 0.38 & 2.25 & 9.32 \\
\hline \multirow[t]{3}{*}[25]{} & $\begin{array}{l}\text { Spanish traditional smoked meat (pork) sausages } \\
\text { in natural casings, produced by different industrial } \\
\text { pork manufacturers by traditional smoking: }\end{array}$ & & & \\
\hline & Chorizo gallego & 0.74 & $-{ }_{c}^{c}$ & 49.78 \\
\hline & Chorizo de cabolla & 1.13 & $-^{c}$ & 53.54 \\
\hline
\end{tabular}

${ }^{a}$ Samples are described in accordance with data given in the cited (source) references.

${ }^{\mathrm{b}}$ No data, since EU PAHs were analyzed.

' The exact numerical values on the individual compounds' occurrence were not shown in the original study, only bar plots.

Acknowledgment. The results presented here are obtained within the project no. 172050 supported by the Ministry of Education, Science and Technological Development of the Republic of Serbia and the project "Estimation of chemical safety of market basket and population dietary exposure" supported by Secretariat for Science and Technological Development of the Province of Vojvodina, both coordinated by Prof. B. Škrbić.

\section{REFERENCES}

[1] L. C. Roseiro, A. Gomes, C. Santos, Influence of processing in the prevalence of polycyclic aromatic hydrocarbons in a Portuguese traditional meat product, Food Chem. Toxic., 49, 1340-1345 (2011).

[2] F. J. Conde, J. H. Ayala, A. M. Afonso, V. González, Polycyclic aromatic hydrocarbons in smoke used to 
smoke cheese produced by the combustion of rock rose (Cistus monspeliensis) and tree heather (Erica arborea) wood, J. Agric. Food Chem., 53, 176-182 (2005).

[3] M. S. García Falcón, J. Simal-Gandara, Polycyclic aromatic hydrocarbons in smoke from different woods and their transfer during traditional smoking into chorizo sausages with collagen and tripe casing, Food Addit. Contam., 22, 1-8 (2005).

[4] V. A. Du Four, C. R. Janssen, E. Brits, N. Van Larebeke, Genotoxic and mutagenic activity of environmental air samples from different rural, urban and industrial sites in Flanders, Belgium, Mutat. Res., 588, 106117 (2005).

[5] US Environmental Protection Agency. Polycyclic organic matter, www.epa.gov/ttn/atw/hlthef/polycycl.html, Washington, DC: Environmental Protection Agency, 2002.

[6] Commission Regulation (EC) No 208/2005 of 4 February 2005 amending Regulation (EC) No 466/2001 as regards polycyclic aromatic hydrocarbons, Official Journal of the European Union, L 34, 3-5 (2005).

[7] Commission Regulation (EC) No 466/2001 of 8 March 2001 setting maximum levels for certain contaminants in foodstuffs, Official Journal of the European Communities, L 77, 1-13 (2001).

[8] Commission Regulation 1881/2006 of 19 December 2006 setting maximum levels for certain contaminants in foodstuffs, Official Journal of the European Union, L 364, 5-24 (2006).

[9] Commission Recommendation 2005/108/EC of 4 February 2005 on the further investigation into the levels of polycyclic aromatic hydrocarbons in certain foods, Official Journal of the European Union, L 34, 43-45 (2005).

[10] Scientific Committee on Food, Opinion of the Scientific Committee on Food on the risk to human of polycyclic aromatic hydrocarbons in food, SCF/CS/CNTM/ PAH/29 Final. Health and consumer protection directorategeneral, Brussels, 2002.

[11] JECFA. Evaluation of certain food contaminants. In WHO (Ed.), WHO technical report series 930, Geneva: JECFA, 2006.

[12] EFSA, Polycyclic aromatic hydrocarbons in 426 food Scientific opinion of the panel on contaminants in the food chain on a request from the European Commission on Polycyclic Aromatic Hydrocarbons in Food, The EFSA Journal, 724 (2008).

[13] Commission Regulation 835/2011 of 19 August 2011 amending Regulation (EC) No 1881/2006 as regards maximum levels for polycyclic aromatic hydrocarbons in foodstuffs, Official Journal of the European Union, $\mathbf{L}$ 215, 4-8 (2011).

[14] Quality requirements for meat products, Official Journal of Serbia and Montenegro, 33, 37 (2004).

[15] B. K. Larsson, Polycyclic aromatic hydrocarbons in smoked fish, Zeitschrift für Lebensmittel-Untersuchung und - Forschung, 174, 101-107 (1982).
[16] Commission Regulation (EU) No 836/2011 of 19 August 2011 amending Regulation (EC) No 333/2007 laying down the methods of sampling and analysis for the official control of the levels of lead, cadmium, mercury, inorganic tin, 3-MCPD and benzo(a)pyrene in foodstuffs, Official Journal of the European Union, L 215, 9-16 (2011).

[17] O. Viegas, P. Novo, O. Pinho, I. M. P. L. V. O. Ferreira, A comparison of the extraction procedures and quantification methods for the chromatographic determination of polycyclic aromatic hydrocarbons in charcoal grilled meat and fish, Talanta, 88, 677-683 (2012).

[18] O. Viegas, P. Novo, E. Pinto, O. Pinho, I. M. P. L. V. O. Ferreira, Effect of charcoal types and grilling conditions on formation of heterocyclic aromatic amines (HA) and polycyclic aromatic hydrocarbons (PAHs) in grilled muscle foods, Food Chem. Toxicol., 50, 21282134(2012).

[19] I. Martorell, G. Perelló, R. Martí-Cid, V. Castell, J. M. Llobet, J. L. Domingo, Polycyclic aromatic hydrocarbons (PAH) in foods and estimated PAH intake by the population of Catalonia, Spain: Temporal trend, Environ. Int., 36, 424-432 (2010).

[20] J. M. Lorenzo, L. Purrinos, M. C. García Fontán, D. Franco, Polycyclic aromatic hydrocarbons (PAHs) in two Spanish traditional smoked sausage varieties: "Androlla" and "Botillo", Meat Sci., 86, 660-664 (2010).

[21] S. L. Ralston, H. H. S. Lau, A. Seidel, A. Luch, K. L. Platt, W. M. Baird, The potent carcinogen diben$\mathrm{zo}[\mathrm{a}, 1]$ pyrene is metabolically activated to fjord-region 11,12-diol 13,14-epoxides in human mammary carcinoma mcf-7 cell cultures, Cancer Res., 54, 887-890 (1994).

[22] A. Gomes, C. Santos, J. Almeida, M. Elias, L. C. Roseiro, Effect of fat content, casing type and smoking procedures on PAHs contents of Portuguese traditional dry fermented sausages, Food Chem. Toxicol. (2013), http://dx.doi.org/10.1016/j.fct.2013.05.015

[23] L. C. Roseiro, A. Gomes, L. Patarata, C. Santos, Comparative survey of PAHs incidence in Portuguese traditional meat and blood sausages, Food Chem. Toxic., 50, 1891-1896 (2012).

[24] M. Pöhlmann, A. Hitzel, F. Schwägele, K. Speer, W. Jira, Contents of polycyclic aromatic hydrocarbons $(\mathrm{PAH})$ and phenolic substances in Frankfurter-type sausages depending on smoking conditions using glow smoke, Meat Sci., 90, 176-184 (2012).

[25] J. M. Lorenzo, L. Purrinos, R. Bermudez, N. Cobas, M. Figueiredo, M. C. García Fontán, Polycyclic aromatic hydrocarbons (PAHs) in two Spanish traditional smoked sausage varieties: "Chorizo gallego" and "Chorizo de cebolla", Meat Sci., 89, 105-109 (2011).

[26] I. Strumpe-Vīksna, V. Bartkevičs, A. Kukāre, A. Morozovs, Polycyclic aromatic hydrocarbons in meat smoked with different types of wood, Food Chem., 110, 794 797 (2008).

[27] Statistical Office of the Republic of Serbia, 2011. http://webrzs.stat.gov.rs/WebSite/ 